\title{
Identification of Nyssopsora thwaitesii on Schefflera in northeast India
}

\author{
P. Baiswar • S. V. Ngachan $\cdot$ S. Chandra
}

Received: 26 July 2013 / Accepted: 24 January 2014 / Published online: 13 February 2014

(C) Australasian Plant Pathology Society Inc. 2014

\begin{abstract}
During a routine survey rust was found on Schefflera wallichiana in Meghalaya in NovemberDecember 2012. Microscopic studies with light and scanning electron microscopy revealed the pathogen to be Nyssopsora thwaitesii. Molecular characterisation of the pathogen was also done by sequencing (18S), ITS region and large subunit (25S) of nrDNA of $N$. thwaitesii. This is the first identification of this pathogen on $S$. wallichiana from northeast India.
\end{abstract}

Keywords Schefflera wallichiana $\cdot$ Nyssopsora thwaitesii . Tuberculina sp · Hyperparasite · LSU · SSU · ITS

Schefflera wallichiana is used as fodder for animals and locally known as Parari grass. Synonyms include Aralia wallichiana, Heptapleurum wallichianum and Paratropia wallichiana (The Plant List 2010). Rust was observed on Schefflera wallichiana during November and December, 2012 in Barapani, Meghalaya, India. Rust pustules appeared as black powdery masses on both leaf surfaces, covering large areas of up to $3 \mathrm{~cm}$ with yellowish margins (Fig. 1). Spots were raised in most of the cases. Both older and younger leaves appeared to be equally susceptible.

Measurements were made after mounting spores in $3 \%$ $\mathrm{KOH}$ at $1,000 \times$ using an Olympus BX 53 microscope equipped with a digital camera DP 72 (Olympus) and image analysis software (cellSens Standard 1.5, Olympus).

P. Baiswar $(\bowtie) \cdot$ S. V. Ngachan $\cdot$ S. Chandra ICAR Research Complex for NEH Region, Umiam 793103, Meghalaya, India

e-mail: pbaiswar@yahoo.com
Scanning electron microscopy was conducted by sputter coating the dried specimens in a JFC-1100 fine coat ion sputter device (JEOL, Tokyo, Japan) under vacuum and then mounted on stubs and observed at $20 \mathrm{kV}$ in JEOL JSM 6360 scanning electron microscope (JEOL, Tokyo, Japan).

For confirmation of generic identity $18 \mathrm{~S}$ (SSU), ITS region and 25S (LSU) regions of nrDNA was also used. DNA isolation was done using the Qiagen stool kit. Primers (NS5, NS 7 and 5'-TCAACAGACTTGTACATGGTCCA3' (a minor modification of ITS4BR)) were used for amplification in a nested PCR (first round NS 5 and modified ITS4BR and second round with NS 7). Cycling conditions had initial denaturation $5 \mathrm{~min}\left(94{ }^{\circ} \mathrm{C}\right)$, denaturation $30 \mathrm{~s}$ $\left(94{ }^{\circ} \mathrm{C}\right)$, annealing $50 \mathrm{~s}\left(55-50{ }^{\circ} \mathrm{C}\right.$, touchdown with $1{ }^{\circ} \mathrm{C}$ decrement in every cycle up to 6 cycles), extension $1: 20 \min \left(72{ }^{\circ} \mathrm{C}\right)$ and final extension $5 \min \left(72{ }^{\circ} \mathrm{C}\right)$ ( 38 cycles). For amplification of the $25 \mathrm{~S}$ (LSU) region of the Nyssopsora sp., the nested PCR was done using primers 5'-GGACCATGTACAAGTCTGTTGA-3' (ITS4BrF) and 5'-CCTGAGGGAAACTTCG-3' (LR 5) for the first round and ITS4BrF and 5'-CCGTGTTTCAAGACGGG -3' (LR 3 ) for the second round. Amplified products were checked through electrophoresis using ethidium bromide. Similarity searches were done using Blastn at NCBI.

Pathogen description: Spermagonia, aecia and uredinia unknown. Telia amphigenous, subepidermal in origin, erumpent, blackish, in large groups measuring 130-460 $\mu \mathrm{m}$ (Fig. 2a). Teliospores chestnut brown when mature, three celled, triquetrous and strongly constricted at the septum, measuring $27-42 \times 22-35 \mu \mathrm{m}$, wall thickness 1-3 $\mu \mathrm{m}$ (Fig. 2b, c). Young pale cinnamon brown teliospores often mixed with mature ones. One to two germpores in each cell of the teliospore. Projections up to 15 and branched at the tips measuring $11-14 \times 5-7 \mu \mathrm{m}$. 


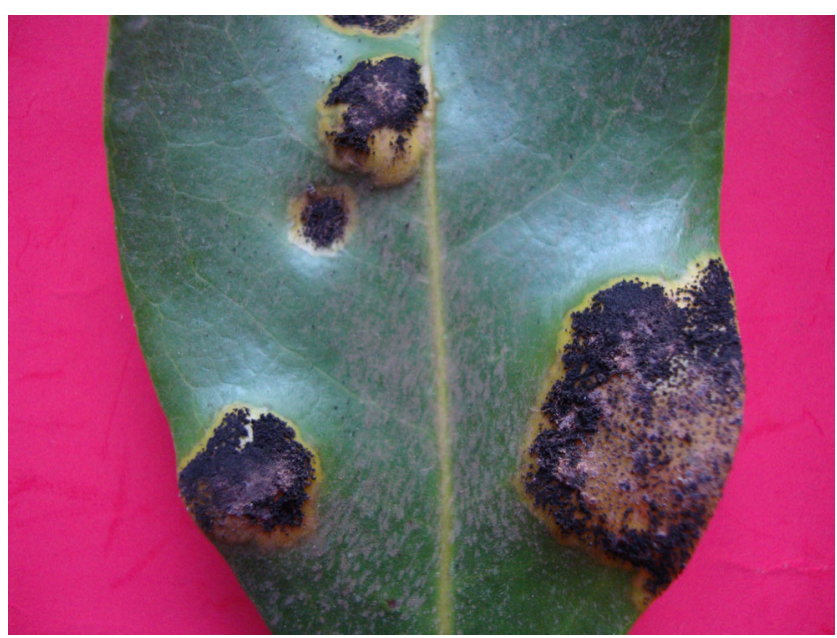

Fig. 1 Symptoms of rust on Schefflera wallichiana

Pedicel persistent, hyaline measuring $35-52 \times 5-7 \mu \mathrm{m}$ (Fig. 2d). Samples have been deposited in the herbarium collection of MACS Agharkar Research Institute, Pune (AMH 9528).

Generic characters of Nyssopsora-Spermagonia unknown. Aecia are uredinoid if present without paraphyses. Aeciospores echinulate. Uredinia subepidermal, erumpent. Telia subepidermal. Teliospores three celled with conspicuous projections and germpores 1-4 (Cummins and Hiratsuka 2003). Therefore, based on 3-celled teliospores with conspicuous projections, we assigned our pathogen to Nyssopsora.

Nyssopsora sp. has been reported on Anacardiaceae, Araliaceae, Meliaceae, Naucleaceae, Pittosporaceae, Sapindaceae and Umbelliferae. In the Araliaceae family, $N$. asiatica (on Aralia and Schefflera), N. clavellosa (on Aralia), N. thwaitesii (Brassiopsis, Hedera, Schefflera), $N$. trevesiae (Trevesia), and N. thirumulacharii (on Brassiopsis griffithi) are reported. Nyssopsora thwaitesii has been reported on S. bengalensis, S. stellata, S. roxburgii and S. venulosum (Monson 1974; Ngachan and Goswami 1985; Bagyanarayana et al. 1987; Lohsomboon et al. 1990).

Our identification is based on the presence of telia on both leaf surfaces (amphigenous) and teliospores strongly constricted at the septum. Nyssopsora thwaitesii differs from $N$. trevesiae in having projections branched at the tips, from $N$. clavellosa in having strong septal constriction in teliospores, from $N$. asiatica in having amphigenous telia, from $N$. thirumulacharii by the presence of furcated projections (type specimen was also obtained from Kew (M) for observations on projections). $N$. cedraleae and $N$. koelreuteriae are not reported on Araliaceae. Nyssopsora cedraleae, $N$. koelreuteriae and $N$. formosana are not reported on Araliaceae; $N$. cedraleae and $N$. formosana also having aeciospores. Nyssopsora schefflerae is now considered

Fig. 2 a Telia of Nyssopsora thwaitesii on Schefflera wallichiana $(\mathrm{Bar}=200 \mu \mathrm{m}) \mathbf{b}$ Teliospores of Nyssopsora thwaitesii $(\mathrm{Bar}=10 \mu \mathrm{m}) \mathbf{c}$ Teliospores of Nyssopsora thwaitesii $(\mathrm{Bar}=100 \mu \mathrm{m}) \mathbf{d}$ Teliospore of Nyssopsora thwaitesii $($ Bar $=10 \mu \mathrm{m}) \mathbf{e}$ Furcated projections on teliospore of Nyssopsora thwaitesii (Bar= $2 \mu \mathrm{m})$

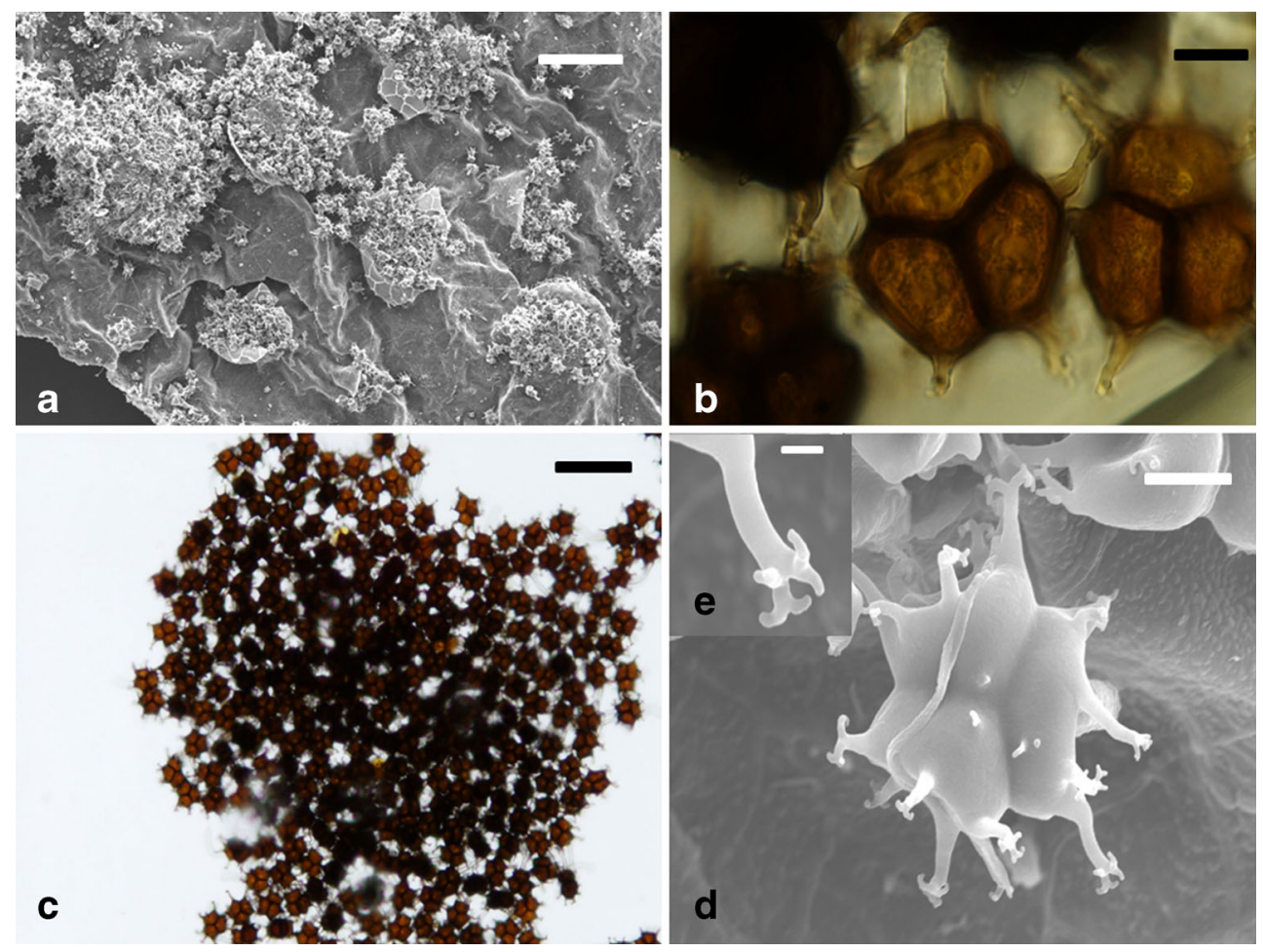




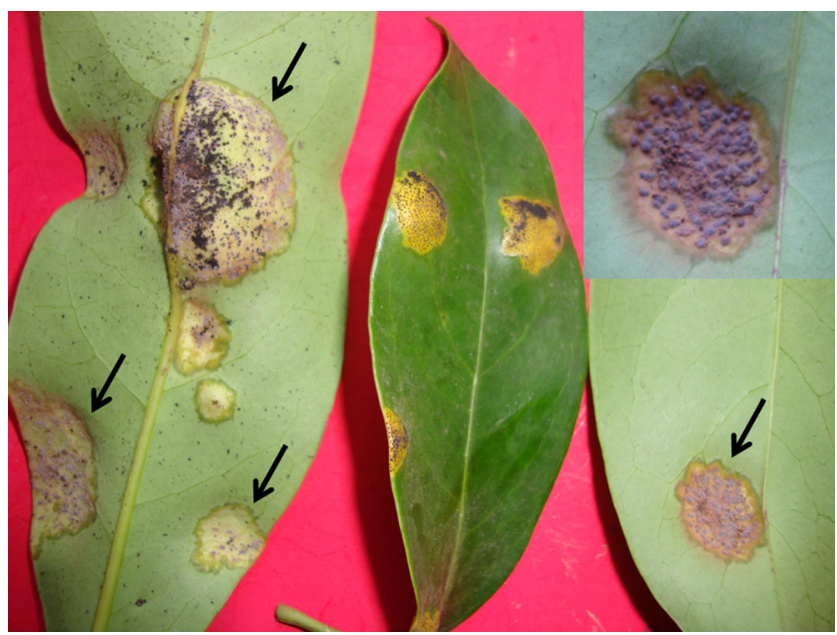

Fig. 3 Parasitised pustules of rust (Nyssopsora thwaitesii) by Tuberculina sp.

synonymous with $N$. thwaitesii (Monson 1974; Ngachan and Goswami 1985; Bagyanarayana et al. 1987; Lohsomboon et al. 1990). Based on these facts we conclude that the species under consideration is $N$. thwaitesii.

Sequences of the SSU and ITS region (KF850482) and 25S (LSU) region (KF550283) have been deposited in Genbank. Blastn search using SSU and ITS region revealed $96 \%$ identity with AY123312.1 and U77061.1 sequences of $N$. echinata. These are the only two sequences of Nyssopsora available in
Genbank. Blastn search using 25S (LSU) (KF550283) revealed $93 \%$ identity with Gymnosporangium sp. since currently no LSU sequence of Nyssopsora is available in Genbank. Our sequence (KF550283) is the first sequence of LSU nrDNA of N. thwaitesii deposited in Genbank.

We also observed during our study that a few rust pustules (teliosori) were also parasitised by Tuberculina sp. also known as purple mold. Parasitised pustules had a tinge of violet colour (Fig. 3). SEM studies revealed that whole pustules were parasitized by Tuberculina sp. with profuse sporulation (Fig. 4). Microscopic studies were conducted as stated above using light and scanning electron microscope. Conidial dimensions were 9-13 $\mu \mathrm{m}$. The sequence containing $18 \mathrm{~S}$ (SSU), ITS region and large subunit of nrDNA has been deposited in GenBank (KC884701). Blastn search revealed maximum identity with Helicobasidium mompa (93\% with sequences AY292428 and AY292429). Many Tuberculina sp. are considered to be anamorphs of Helicobasidium sp., parasites of rust and also closely related to rusts (Lutz et al. 2004a, b).

This is the first identification of $N$. thwaitesii on $S$. wallichiana from India. Nyssopsora thwaitesii is reported on $S$. bengalensis, S. stellata, S. roxburgii and $S$. venulosum in mainland (central and southern parts of India) but not from northeast India nor neighbouring Myanmar, Bangladesh and Bhutan (Farr and Rossman 2012). It is of economic significance since this plant is used as fodder in this region.
Fig. 4 a Parasitised pustules of rust (Nyssopsora thwaitesii) by Tuberculina sp. (Bar $=100 \mu \mathrm{m}) \mathbf{b}$ Non-parasitised pustules of rust (Nyssopsora thwaitesii) by Tuberculina $\mathrm{sp}$. (Bar $=50 \mu \mathrm{m}) \mathbf{c}$ Conidia of Tuberculina sp. (Bar $=5 \mu \mathrm{m}) \mathbf{d}$ Conidia of Tuberculina sp. on teliospore of Nyssopsora thwaitesii

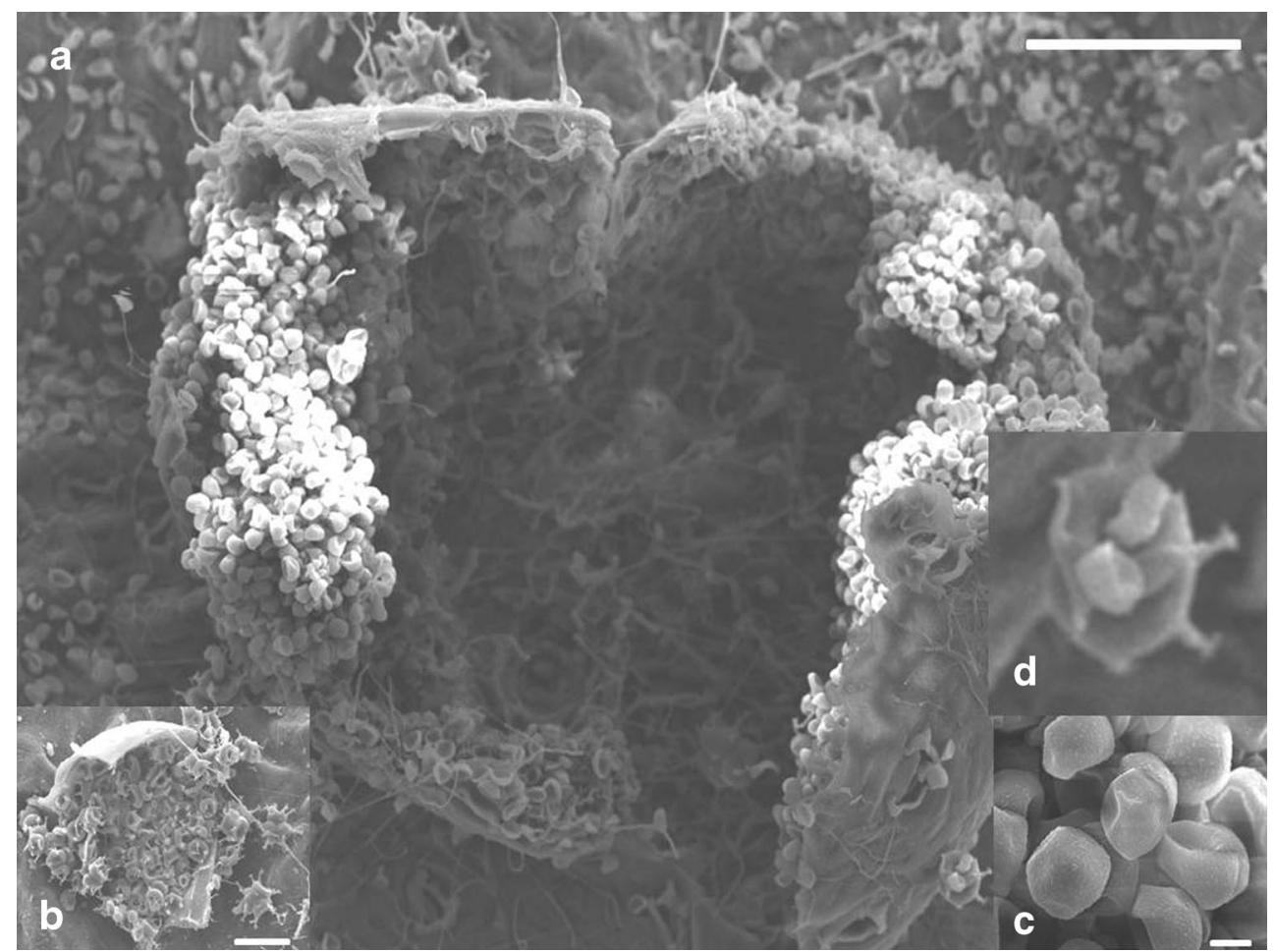


Acknowledgments Animal Production (including Poultry Science) is thanked for providing facilities for molecular work. Authors would like to thank Head SAIF, Dr Sudeep Dey (Scientific Officer), N. K. Rynjah, and Dr R. Charkraborty for scanning electron microscopy at Northeastern Hill University, Shillong, Meghalaya, India. Authorities at Kew K(M), England are thanked for loan of type specimen of $N$. thirumulacharii. Microscope (Olympus BX 53) used has been procured under National Initiative on Climate Resilient Agriculture (NICRA) project (PI, Dr DJ Rajkhowa). Dr P Singh, Animal Nutrition is also thanked for information on host plant.

\section{References}

Bagyanarayana G, Subbalakshmi G, Ramachar P, Hosagoudar VB (1987) Nyssopsora scheflerae sp. nov. from India. Curr Sci 56:1022-1023
Cummins GB, Hiratsuka Y (2003) Illustrated genera of rust fungi, 3rd edn. APS Press, St. Paul

Farr DF, Rossman AY (2012) Fungal databases, systematic botany \& mycology laboratory, USDA: ARS. Available at http://nt.ars-grin. gov/fungaldatabases (Retrieved December 7, 2012)

Lohsomboon P, Kakishima M, Ono Y (1990) A revision of the genus Nyssopsora (Uredinales). Mycol Res 94:907-922

Lutz M, Bauer R, Begerow D, Oberwinkler F (2004a) TuberculinaThanatophytum/Rhizoctonia crocorum-Helicobasidium: a unique mycoparasitic-phytoparasitic life strategy. Mycol Res 108:227-238

Lutz M, Bauer R, Begerow D, Oberwinkler F, Triebel D (2004b) Tuberculina: rust relatives attack rusts. Mycologia 96:614-626

Monson HL (1974) The species of Triphragmium, Nyssopsora, and Triphragmiopsis. Mycopathol Mycol Appl 52:115-131

Ngachan SV, Goswami RN (1985) Nyssopsora thirumulacharii- a new rust from India. Indian Phytopathol 38:186-187 